\title{
Genetic Linkage between Runnering and Phosphoglucoisomerase Allozymes, and Systematic Distortion of Monogenic Segregation Ratios in Diploid Strawberry
}

\author{
Hongrun Y $\mathbf{u}^{1}$ and Thomas $M$. Davis ${ }^{2}$ \\ Department of Plant Biology, University of New Hampshire, Durham, NH 03824
}

\begin{abstract}
Additional index words. PGI-2
Abstract. As part of a strawberry (Fragaria sp.) genome mapping project, we studied the linkage relationship between runnering and phosphoglucoisomerase PGI-2 allozymes in diploid strawberry. The respective $r$ and Pgi-2 loci were found linked with a recombination frequency of $18.1 \% \pm 1.6 \%$ (a map distance of $18.9 \pm 1.6 \mathrm{cM}$ ). This is the second reported linkage in strawberry. The linkage between runnering and phosphoglucoisomerase allozymes, if conserved at the octoploid level, might provide a means of marker-assisted selection for the nonrunnering and bushy branching growth habits in cultivated strawberry. Severe distortion of monogenic segregation ratios was observed for runnering and PGI2, and also for an unlinked locus for shikimate dehydrogenase allozymes. Alleles from the perpetual flowering (alpine $F$. vesca) parents were favored in this distortion. This phenomenon should be considered in future genetic studies using crosses between alpine and nonalpine strawberries.
\end{abstract}

The strawberry (Fragaria sp.) is an excellent subject for genetic and evolutionary studies for many reasons. It is a popular fruit of significant economic importance. The genus has widespread distribution and high genetic diversity in its natural habitats across Asia, Europe, and the Americas (Hancock and Luby, 1993; Luby et al., 1992). There are at least 20 different species and four ploidy levels (Staudt, 1962, 1989). It frequently and spontaneously hybridizes to produce natural hybrids, including interspecific hybrids across ploidy levels (Bringhurst, 1990). The hybrid forms are preserved by vegetative propagation. However, genetic research has been hampered by the genetic complexity stemming from polyploidy, particularly in octoploid cultivated strawberry $(F$. $\times$ ananassa Duch., $2 \mathrm{n}=8 \mathrm{x}=56$ ). Several authors (Arulsekar and Bringhurst, 1983; Brown and Wareing, 1965; Davis and Pollard, 1991; Williamson et al., 1995) point out that, since there is a similar spectrum of character variation (e.g., seasonal vs. perpetual flowering, runnering vs. nonrunnering) and intercrossability between polyploid and diploid species, the most common diploid species, F. vesca $\mathrm{L} .(2 \mathrm{n}=2 \mathrm{x}=14)$, can be used as a model system to study strawberry genes and their linkage relationships.

Only a few morphological traits of Mendelian inheritance have been studied in strawberry (Galletta and Maas, 1990). Of these, two are perpetual flowering (overbearing) and nonrunnering habits associated with the so-called alpine varieties, a group of $F$. vesca of European origin. Brown and Wareing (1965) found that each of these two traits was controlled by a single recessive gene (s/s and $r / r$, respectively). Their results indicated no genetic linkage between flowering and runnering, although the wild type (seasonal flowering, runnering) ceased runner production when

Received for publication 15 Sept. 1994. Accepted for publication 4 Jan. 1995. This is scientific contribution 1879 from the New Hampshire Agricultural Experiment Station. This research was supported in part by U.S. Dept. of Agriculture plant genome program grant \#92-27300-7442. All crosses were made by Scott Williamson. Kathy Cruz and Lynn Boyden assisted with the isozyme analysis. The cost of publishing this paper was defrayed in part by the payment of page charges. Under postal regulations, this paper therefore must be hereby marked advertisement solely to indicate this fact.

${ }^{1}$ Postdoctoral research associate.

${ }^{2}$ Associate professor to whom reprint requests should be addressed. flowering. In that study, bushy branching was correlated with nonrunnering in a cross involving the alpine variety 'Bush White', but the genetic basis for this correlation was not established. An $F$. vesca arboreal mutant (with long internodes) was discovered by Staudt (1959), who showed that it was a monogenic recessive mutation (arb/arb). In a crossing and backcrossing study involving this mutant ( $a r b / a r b, R / R)$ and an alpine variety (Arb/Arb, $r / r)$, no runnerless progeny were recovered, suggesting an epistatic effect of the arboreal locus to the runnering locus (Guttridge, 1973).

The genetics of several isozyme systems have been studied in strawberry. These include phosphoglucoisomerase (PGI), phosphoglucomutase (PGM), esterase (EST), leucine aminopeptidase

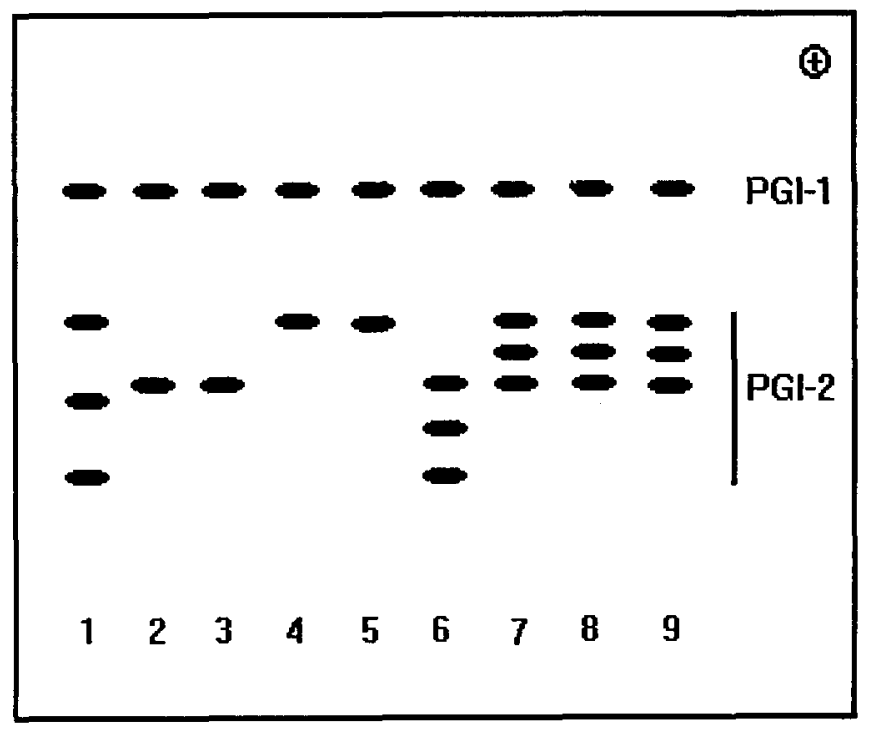

Fig. 1. PGI zymograms of diploid strawberry plants, Lane 1, FRA 364: Pgi-2 ${ }^{c} / P g i-$ 2; Lanes 2-3, 'Yellow Wonder' and 'Baron Solemacher', respectively: Pgi-2 ${ }^{a}$ / Pgi-2 $2^{a}$; Lanes 4-5, WC6 and WC40, respectively: Pgi-2'/Pgi-2'; Lane 6, F plant GB of FRA 364 x 'Yellow Wonder': Pgi-2 ${ }^{\circ} /$ Pgi-2'; Lanes 7-9, F, plant S of FRA $364 \mathrm{x}$ 'Yellow Wonder', $\mathrm{F}$, of 'Baron Solemacher' $\mathrm{x}$ WC6, and $\mathrm{F}_{1}$ of 'Baron Solemacher' $\mathrm{x}$ WC40, respectively: $P g i-2^{a} / P g i-2^{c}$. 
(LAP), phosphogluconate dehydrogenase (PGD), and shikimate dehydrogenase (SDH) (Arulsekar and Bringhurst, 1981; Arulsekar et al., 1981; Bringhurst et al., 1981; Nehra et al., 1991; Williamson et al., 1995). PGI is the most well-characterized. The most anodal isozyme on the gel, denoted as PGI-1, is invariant and probably chloroplast-associated. The nucleus-controlled PGI-2 isozyme is slower than PGI-1 on the gel. Three alleles were detected for PGI2 in California diploid populations, existing in either homozygous or heterozygous genotypes (Arulsekar and Bringhurst, 1981). Symbols $P g i-2 b, P g i-2 c$, and Pgi-2d were assigned for the slow, medium, and fast alleles, respectively, according to the nobilities of the allozymes they produced on the gel. The alpine varieties carry a distinctive, slower, fourth allozyme, with the allele designation of Pgi-2a (Arulsekar and Bringhurst, 1981). A four-locus genetic model (one for each of the four homologous genomes) was proposed for the PGI-2 allozymes of octoploid cultivated strawberry (Arulsekar et al., 1981). These four loci can be fixed for one allele, producing only one band on the gel, or heterozygous at one or more of the four loci, generating multiple homodimer and heterodimer bands. Alleles Pgi-2a, Pgi-2b, Pgi-2c, and Pgi-2e (even slower than alpine $P g i-2 a$ ) were present in the California cultivated strawberry (Arulsekar et al., 1981).

The inheritance of SDH in $F$. vesca was reported recently (Williamson et al., 1995). It is a monomeric enzyme. A single polymorphic band was observed in a survey of several diploid Fragaria species (unpublished data). Hybridization experiments suggested that the bands in these species represented allozymes controlled at a single locus, which was designated as $S d h$.
There had been no quantified linkages reported in any strawberry species until recently it was found that the $S d h$ gene was tightly linked $(1.1 \mathrm{cM})$ to a fruit color gene $(c)$ in $F$. vesca (Williamson et al., 1995). Here, we document a second linkage in the diploid strawberry-in this case, between the runnering gene (r) and Pgi-2.

\section{Materials and Methods}

Fragaria vesca alpine varieties 'Baron Solemacher' and 'Yellow Wonder' (both nonrunnering) were obtained as seed from Johnny's Select Seeds, Albion, Maine, and W. Atlee Burpee and Co., Warminster, Pa., respectively. Diploid accession FRA 364 (runnering) was obtained as a runner clone from the National Clonal Germplasm Repository, Corvallis, Ore. It was listed as $F$. vesca, but we now question this identification, as discussed later. Fragaria vesca accessions WC6 and WC40 (both runnering) were collected by Tom Davis, Jim Pollard, and Scott Williamson in the wild from Diamond Peak Trail (Dartmouth College second grant) and Weeks State Park, respectively, in New Hampshire. .

The following crosses were made in the greenhouse at the Univ. of New Hampshire: 'Yellow Wonder' $x$ FRA 364, 'Baron Solemacher' $x$ WC6, and 'Baron Solemacher' x WC40. Four $F_{2}$ and two $\mathrm{F}_{3}$ populations were derived for the linkage analyses of runnering and PGI-2. Because of the presence of heterozygosity in FRA 364, the $F_{1}$ population of 'Yellow Wonder' $x$ FRA 364 was segregating for many markers, and the individual $F_{1}$ plants were labeled alphabetically. The $F_{2}$ families from two particular $F_{1}$

Table 1. Joint segregation of runnering and PGI-2 allozymes in diploid strawberry.

\begin{tabular}{|c|c|c|c|c|c|c|c|c|c|c|}
\hline \multirow{3}{*}{ Population } & \multicolumn{6}{|c|}{ Dihybrid phenotypes and frequencies ${ }^{z}$} & \multirow[b]{2}{*}{$\mathrm{N}$} & \multirow[b]{2}{*}{$\chi^{2 y}$} & \multirow[b]{2}{*}{$P$} & \multirow[b]{2}{*}{$r(\%)^{\mathrm{x}}$} \\
\hline & \multicolumn{3}{|c|}{$\mathrm{R}+$} & \multicolumn{3}{|c|}{$\mathrm{R}-$} & & & & \\
\hline & $F(e+f)$ & $\mathrm{H}(\mathrm{g}+\mathrm{h}+\mathrm{i})$ & $S(\bar{j}+k)$ & $\overline{F(1)}$ & $\mathrm{H}(\mathrm{m})$ & $\mathrm{S}(\mathrm{n})$ & & & & \\
\hline $\mathrm{F}_{3}^{2} \mathrm{~GB}-2$ & 6 & 50 & 12 & 38 & 14 & 3 & 123 & 48.09 & $<0.01$ & 16.9 \\
\hline \multirow{2}{*}{$\mathrm{F}_{3} \mathrm{~GB}-12$} & 6 & 36 & 9 & 28 & 13 & 0 & 91 & 32.30 & $<0.01$ & 16.6 \\
\hline & $S(e+f)$ & $\mathrm{H}(\mathrm{g}+\mathrm{h}+\mathrm{i})$ & $F(j+k)$ & $S(1)$ & $\mathrm{H}(\mathrm{m})$ & $\mathrm{F}(\mathrm{n})$ & & & & \\
\hline $\mathrm{F}_{2}^{2} \mathrm{BS} \times \mathrm{WC} 40$ & 3 & 23 & 4 & 19 & 15 & 2 & 66 & 13.55 & $<0.01$ & 24.8 \\
\hline
\end{tabular}

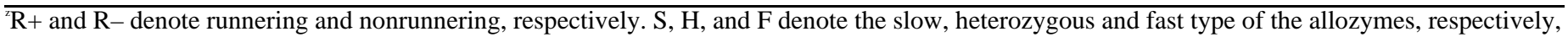
and are population-specific. Allard's (1956) dihybrid genotypic classifications in repulsion phase are given in parentheses. The expected segregation ratio is $3: 6: 3: 1: 2: 1$ for $(\mathrm{e}+\mathrm{f}):(\mathrm{g}+\mathrm{h}+\mathrm{i}):(\mathrm{j}+\mathrm{k}): 1: \mathrm{m}: \mathrm{n}$.

${ }^{y}$ Contingency chi-square with $\mathrm{df}=2$.

${ }^{\mathrm{x}}$ Recombination frequency.

Table 2. Alpine allele $(r)$ frequency for nonrunnering in diploid strawberry.

\begin{tabular}{|c|c|c|c|c|c|c|}
\hline \multirow[t]{2}{*}{ Population } & \multicolumn{2}{|c|}{$\begin{array}{l}\text { Phenotypic } \\
\text { frequencies }^{z}\end{array}$} & \multirow{2}{*}{\multicolumn{2}{|c|}{$\begin{array}{c}\chi^{2} \\
(3: 1) \\
\end{array}$}} & \multirow[t]{2}{*}{$P$} & \multirow[t]{2}{*}{$\begin{array}{c}\text { Alpine allele } \\
\text { frequency }\end{array}$} \\
\hline & $R+$ & $R-$ & & & & \\
\hline $\mathrm{F}_{2} \mathrm{~GB}$ & 45 & 45 & 90 & 30.00 & $<0.01$ & 0.71 \\
\hline $\mathrm{F}_{3}$ GB-2 & 68 & 55 & 123 & 25.49 & $<0.01$ & 0.67 \\
\hline $\mathrm{F}_{3}^{3} \mathrm{~GB}-12$ & 51 & 40 & 91 & 17.44 & $<0.01$ & 0.66 \\
\hline $\mathrm{F}_{2}^{3} \mathrm{~S}$ & 134 & 103 & 237 & 43.07 & $<0.01$ & 0.66 \\
\hline $\mathrm{F}_{2}^{2} \mathrm{BS} \times \mathrm{WC} 6$ & 55 & 42 & 97 & 17.32 & $<0.01$ & 0.66 \\
\hline $\mathrm{F}_{2} \mathrm{BS} \times \mathrm{WC} 40$ & 30 & 36 & 66 & 30.73 & $<0.01$ & 0.74 \\
\hline Mean & & & & & & 0.68 \\
\hline
\end{tabular}

${ }^{\overline{ }} \mathrm{R}+$ and $\mathrm{R}-$ denote runnering and nonrunnering, respectively. 
plants, GB and $\mathrm{S}$, provided two segregating populations (referred to as $\mathrm{F}_{2} \mathrm{~GB}$ and $\mathrm{F}_{2} \mathrm{~S}$, respectively). The $\mathrm{F} 3$ progenies of $\mathrm{F}_{2}$ plants number GB-2 and GB-12 accounted for two more segregating populations (referred to as $\mathrm{F}_{3} \mathrm{~GB}-2$ and $\mathrm{F}_{3} \mathrm{~GB}-12$, respectively). The other two study populations were the $\mathrm{F}_{2}$ generations of 'Baron Solemacher' x WC6 ( $\mathrm{F}_{2} \mathrm{BS}$ x WC6) and 'Baron Solemacher' $\mathrm{x}$ WC40 ( $\mathrm{F}_{2} \mathrm{BS}$ X WC40).

Plants were grown in clay pots on the benches of the glasshouse, and observed for about 1 year. They were watered regularly. No artificial light was provided. Pipe steam heating was provided in the winter; the minimum temperatures were at $15.5 \mathrm{C}$ at night and 21.0C during the day. Isozyme assays were done for PGI and SDH using young leaf lamina tissues ground in extraction buffer (Bringhurst et al., 1981). Electrophoresis was conducted on gels made of $79 \%$ acrylamide plus $2 \%$ starch as used for soybean (Bult et al., 1989). PGI and SDH activity staining was as described by Williamson et al. (1995). Contingency chi-square analysis was used to detect linkage. Recombination frequencies were calculated using the LINKAGE- 1 computer program (Suiter et al., 1983). A homogeneity chi-square test was performed according to Allard (1956). We also calculated the frequencies of alpine vs. nonalpine alleles in the six populations. Alpine nonrunnering allele frequency was the square root of the proportion of nonrunnering plants in the population. Alpine allele frequency for the isozymes was the proportion of one-half the number of heterozygotes plus alpine homozygotes in the population.

\section{Results and Discussion}

The PGI phenotypes of the crossing parents and $\mathrm{F}_{1}$ plants used in the analyses are shown in Fig. 1. Three-banded PGI-2 phenotypes were observed in $F_{1}$ plants of all crosses (Fig. 1). One of the parents, FRA 364, also displayed a three-banded phenotype. PGI2 was proposed to have a dimeric subunit structure in the strawberry (Arulsekar and Bringhurst, 1981). In heterozygotes, the polypeptide subunits encoded by alternate alleles associate at random to form dimers. As a result, besides the two possible homodimerbands, an intermediate, heterodimerband also appears on the gel. The three-banded phenotype in the FRA 364 parent and the transmission of different alleles to its $F_{1}$ plants GB and S (Fig. 1) indicated that FRA 364 was heterozygous for PGI-2.

Arulsekar and Bringhurst (198 1) assigned allele symbols Pgi$2 b, P g i-2 c$, and Pgi-2d for the three alleles found in California populations of $F$. vesca, and Pgi-2a for the slow allele unique to alpine varieties. By screening Fragaria germplasm, including representatives of California populations (collected in 1992 by Tom Davis), and comparing the band nobilities (unpublished data), we determined that the alleles in WC6 and WC40 and the fast allele in FRA 364 were Pgi-2c. The slow allele of FRA 364, which was slower than the alpine $P g i-2 a$, was also present in accessions FRA 341 and FRA 333 of $F$. viridis Duch., another diploid strawberry species. Arulsekar and Bringhurst (1981) earlier also noted the presence of alleles slower than Pgi-2a in F. viridis. The presence of this slow allele (denoted here as Pgi-2s for convenience) in FRA 364-found in F. viridis but never observed in $F$. vesca-indicated that FRA 364 might be an interspecific hybrid between these two species. Personal communication with R.S. Bringhurst, who originally donated FRA 364 to the germplasm repository, supported this proposition.

Linkage analysis was done for $r$ and Pgi-2. The contingency chi-square test showed significant association of the two loci in all six populations (Table 1). The recombination frequency varied from $13.1 \%$ to $24.8 \%$ and was $18.1 \% * 1.6 \%$ for the pooled data. The homogeneity chi-square among all populations was not sig-

Table 3. Alpine allele frequency for PGI-2 in diploid strawberry.

\begin{tabular}{|c|c|c|c|c|c|c|c|}
\hline \multirow[t]{2}{*}{ Population } & \multicolumn{2}{|c|}{$\begin{array}{c}\text { Phenotypic } \\
\text { frequencies }^{\mathrm{z}}\end{array}$} & & \multirow[t]{2}{*}{$\mathbf{N}$} & \multirow[t]{2}{*}{$\begin{array}{c}\chi^{2} \\
(1: 2: 1)\end{array}$} & \multirow[t]{2}{*}{$P$} & \multirow{2}{*}{$\begin{array}{l}\begin{array}{c}\text { Alpine allele } \\
\text { frequency }^{\mathrm{y}}\end{array} \\
F\end{array}$} \\
\hline & $F$ & $H$ & $\bar{S}$ & & & & \\
\hline $\mathrm{F}_{2} \mathrm{~GB}$ & 35 & 48 & 7 & .90 & 17.82 & $<0.01$ & 0.66 \\
\hline $\mathrm{F}_{3} \mathrm{~GB}-2$ & 44 & 64 & 15 & 123 & 13.87 & $<0.01$ & 0.62 \\
\hline $\mathrm{F}_{3} \mathrm{~GB}-12$ & 31 & 49 & 9 & 91 & 11.57 & $<0.01$ & 0.61 \\
\hline & $S$ & $H$ & $F$ & & & & $S$ \\
\hline $\mathrm{F}_{2} \mathrm{~S}$ & 94 & 115 & 28 & 237 & 36.96 & $<0.01$ & 0.64 \\
\hline $\mathrm{F}_{2} \mathrm{BS} \times \mathrm{WC} 6$ & 39 & 45 & 13 & 97 & 14.44 & $<0.01$ & 0.63 \\
\hline $\mathrm{F}_{2} \mathrm{BS} \times \mathrm{WC} 40$ & 22 & 38 & 6 & 66 & 9.27 & $<0.01$ & 0.62 \\
\hline Mean & . & & & & & & 0.63 \\
\hline
\end{tabular}

${ }^{\bar{z}} \mathrm{~S}, \mathrm{H}$, and $\mathrm{F}$ denote the slow, heterozygous and fast type of the allozymes, respectively, and are population-specific.

${ }^{y} \mathrm{~F}$ and $\mathrm{S}$ denote fast and slow PGI-2 alleles, respectively.

Table 4. Alpine allele frequency for SDH in diploid strawberry.

\begin{tabular}{|c|c|c|c|c|c|c|c|}
\hline Population & & $\begin{array}{l}\text { typic } \\
\text { ncies }^{z}\end{array}$ & & $\mathrm{~N}$ & $\begin{array}{c}\chi^{2} \\
(1: 2: 1)\end{array}$ & $P$ & $\begin{array}{l}\text { Alpine allele } \\
\text { frequency }\end{array}$ \\
\hline & $F$ & $H$ & $S$ & & & & $F$ \\
\hline $\mathrm{F}_{2} \mathrm{~GB}$ & 52 & 22 & 0 & 74 & 85.24 & $<0.01$ & 0.85 \\
\hline \multirow[t]{2}{*}{$\mathrm{F}_{3} \mathrm{~GB}-2$} & 35 & 18 & 0 & 53 & 51.68 & $<0.01$ & 0.83 \\
\hline & $S$ & $H$ & $F$ & & & & $S$ \\
\hline $\mathrm{F}_{2} \mathrm{~S}$ & 64 & $\begin{array}{l}+\quad 109 \\
\end{array}$ & 18 & 191 & 25.98 & $<0.01$ & 0.62 \\
\hline $\mathrm{F}_{2} \mathrm{BS} \times \mathrm{WC} 6$ & 24 & 23 & 3 & 50 & 17.96 & $<0.01$ & 0.71 \\
\hline $\mathrm{F}_{2} \mathrm{BS} \times \mathrm{WC} 40$ & 13 & 26 & 3 & 42 & 7.15 & $<0.05$ & 0.62 \\
\hline Mean & & & & & & & 0.70 \\
\hline
\end{tabular}

${ }^{\bar{z}} \mathrm{~S}, \mathrm{H}$, and $\mathrm{F}$ denote the slow, heterozygous and fast type of the allozymes, respectively, and are population-specific.

${ }_{\mathrm{F}} \mathrm{F}$ and $\mathrm{S}$ denote fast and slow $\mathrm{SDH}$ alleles, respectively. 
nificant, supporting the $18.1 \% \pm 1.6 \%$ recombination frequency and also indicating that the possible hybrid origin of parental FRA 364 was not a confounding factor in this study. The map distance calculated from the pooled data using the LINKAGE- 1 computer program was $18.9 \pm 1.6 \mathrm{cM}$. This result established the second quantified linkage in the strawberry.

If conserved at the octoploid level, the linkage between runnering and PGI-2 may have practical implication in breeding programs. Brown and Wareing (1965) found that nonrunnering was associated with the bushy branching habit in the progeny of a cross involving alpine variety 'Bush White'; hence these two growth habit traits might be governed either by two closely linked genes or by one gene with pleiotropic effects. The bushy type has more fruit-bearing crowns; thus, the bushy branching habit could be a character related to strawberry yield. It would be of interest to know whether any correlation exits between PGI-2 genotypes and the bushy branching growth habit or runnering propensity in the cultivated strawberry Fragaria xananassa.

During the linkage analyses we found that monogenic segregation ratios were severely distorted for runnering and PGI-2. The segregation of phenotypes deviated significantly from the expected ratios in all populations based on a chi-square test (Tables 2 and 3). Further examination revealed that the distortion was systematic, with an excess of alpine-derived alleles compared with the expected proportion. The deviation was consistent across populations. The average alpine allele frequencies of the six populations were 0.67 and 0.63 , respectively, for runnering and PGI-2, which was much higher than the expected 0.50 .

Then, we examined another isozyme, SDH. Monogenic segregation for SDH also showed the same trend of deviation favoring the alpine allele (Table 4). The average frequency was 0.70 for the alpine allele. We found no linkages of SDH with either PGI-2 or runnering. Thus, the existence of the linkage between runnering and PGI-2 was not an artifact of the deviations from the expected segregation ratios at the monogenic level. We speculate that the distorted monogenic segregation ratios favoring alpine alleles may be a common phenomenon in the progeny of crosses involving both the perpetual (alpine) and seasonal flowering varieties. Such a distortion was not observed in previous alpine $\mathbf{x}$ alpine crosses used to detect the SDH-fruit color linkage (Williamson et al., 1995).

The observation of distorted monogenic segregation ratios is important and provides caution in future genetic studies of strawberry, particularly when using crosses involving alpine and nonalpine varieties as parents. For example, by looking at the segregation data for runnering (Table 2), which fit a 9:7 ratio, one might conclude that the runnering trait was controlled by two complementary, dominant genes. However, in the context of the previous inheritance study of nonrunnering (Brown and Wareing, 1965) and the distorted monogenic segregation pattern of the linked Pgi-2 locus, a monogenic basis for runnering vs. nonrunnering is clearly indicated.
The distortion of monogenic segregation ratios was probably caused by the fundamental genetic differences between the two types of $F$. vesca. Using only alpine varieties as female parents in making crosses as we did might have provided cytoplasmic advantage for alpine alleles in our study. Further studies involving reciprocal crosses are needed to determine the cause of the observed distortion of monogenic segregation ratios.

\section{Literature Cited}

Allard, R.W. 1956. Formulas and tables to facilitate the calculation of recombination values in heredity. Hilgardia 24:235-278.

Arulsekar, S. and R.S. Bringhurst. 1981. Genetic model for the enzyme marker PGI in diploid California Fragaria vesca L. J. Hered. 72: 117-120.

Arulsekar, S. and R.S. Bringhurst. 1983. Strawberry, p. 391499. In: S.D. Tanksley and T.J. Orton (eds.). Isozymes in plant genetics and breeding, Part B. Elsevier Science Publishers, Amsterdam.

Arulsekar, S., R.S. Bringhurst, and V. Voth. 1981. Inheritance of PGI and LAP isozymes in octoploid cultivated strawberries. J. Amer. Soc. Hort. Sci. 106:679-683.

Bringhurst, R.S. 1990. Cytogenetics and evolution in American Fragaria. HortScience 25:879-881.

Bringhurst, R. S., S. Andsekar, J.F. Hancock, Jr., and V. Voth. 1981. Electrophoretic characterization of strawberry cultivars. J. Amer. Soc. Hort. Sci. 106:684-687.

Brown, T. and P.F. Wareing. 1965. The genetical control of the everbearing habit and three other characters in varieties of Fragaria vesca. Euphytica 14:97-112.

Bult, C. J., Y.T. Kiang, Y.C. Chiang, J.H.Y. Doong, and M.B. Gorman. 1989. Electrophoretic methods for soybean genetics studies. Soybean. Genet. Nwsl. 16:175-1 87.

Davis, T.M. and J.E. Pollard. 1991. Fragaria vesca chlorophyll mutants. HortScience 26:311.

Galletta, G.J. and J.L. Maas. 1990, Strawberry genetics. HortScience 25:871-879.

Guttridge, C.G. 1973. Stem elongation and runnering in the mutant strawberry, Fragaria vesca L. arborea Staudt. Euphytica 22:357-36 1.

Hancock, J.F. and J.J. Luby. 1993. Genetic resources at our doorstep: The wild strawberries. Bioscience 43: 141-147.

Luby, J.J., J.F. Hancock, Jr., and J.R. Ballington. 1992. Collection of native strawberry germplasm in the pacific northwest and northern Rocky Mountains of the United States. HortScience 27: 12-17.

Nehra, N. S., K.K. Kartha, and C. Stushnoff. 1991. Isozymes as markers for identification of tissue culture and greenhouse-grown strawberry cultivars. Can. J. Plant Sci. 71: 1195-1201.

Staudt, G. 1959. Eine spontan aufgetretene Grossmutation bei Fragaria $v e x-a$ L. Naturwissenschaften 46:23-24.

Staudt, G. 1962. Taxonomic studies in the genus Fragaria. Can. J. Bet. 40:869-883.

Staudt, G. 1989. The species of Fragaria, their taxonomy and geographic distribution. Acta Hort. 265:23-33.

Suiter K.A. J.F. Wendel, and J.S. Case. 1983. LINKAGE-1: A PASCAL computer program for detection and analysis of genetic linkage. J. Hered. 74:203-204.

Williamson, S. C., H. Yu, and T.M. Davis. 1995. Shikimate dehydrogenase allozymes: Inheritance and close linkage to fruit color in the diploid strawberry. J. Hered. 86:74-76. 